\title{
Litteratur
}

Marc Ancel: Social Defence. A Modern Approach to Criminal Problems. Edited by W. J. H. Sprott. Routledge \& Kegan Paul. London 1965, $232 \mathrm{~s}$.

Denne bog er en oversættelse og à jour føring af den franske førsteudgave fra 1954. Dens fremragende forfatter, højesteretsdommeren og kriminalisten Marc Ancel er velkendt overalt, hvor der kæmpes for en human strafferet, baseret på kriminologisk forskning. Særlig kendt er hans virksomhed i skrift og tale ved efterkrigstidens talrige og livlige kongresser på det kriminalistiske område.

Kærnen i arbejdet er en redegørelse for begrebet „socialt forsvar“. Udtrykket har mødt modstand fra kriminalister, som går ind for et straffesystem, der hviler på forestillingen om et etisk skyldprincip (såkaldt neo-klassisk teori) ofte suppleret med en opfattelse af straffen som en retfærdig gengældelse.

En anden ideologisk gruppe, som Ancel på sin side må tage afstand fra, er den, der helt vil bryde med strafferetten i dens klassiske form og helt vil stryge begrebet straf og ansvar i gængs forstand og erstatte dem med social forpligtelse kædet sammen med sociale sanktioner. Opfattelsen er i nyere teori særlig kendt fra Filippo Gramatica's skrifter og det af ham grundede selskab til gennemførelse af et defence-social-program. Det er Ancel magtpåliggende at lægge st $\varnothing r s t$ mulig afstand mellem denne udformning af defence sociale og sit eget „nye social-forsvar". Dette må ikke slås i hartkorn med Lombroso's ideologi, ej heller med visse hasarderede teorier af nye dato.

Ancel betoner, at det nye social-forsvar betyder en vigtig udvikling i moderne kriminalvidenskab. Det indebærer, at man g $\varnothing \mathrm{r}$ sig visse rodfæstede behov i det moderne samfund klart. Det nye social-forsvar har et humanistisk præg og et dynamisk indhold. Eller som det siges i denne forbindelse: social-forsvaret er ikke udtryk for en eksklusiv, ensidig skole. Det beror ikke på noget enkelt dogme. Det - eller som det hyppigt siges af Ancel - bevægelsen for socialt forsvar søger at bringe forståelse mellem forskellige retninger i strafsystemet, og søger tilslutning hos alle, der går ind for en ægte human bevægelse i strafferetten i modsætning til dem, der mest beskæftiger sig med tekniske formaliteter.

I en nærmere analyse af, hvad „social defence“ egentlig er, vender Ancel sig polemisk mod bl. a. professor Erwin Frey, der har gjort sig til talsmand for de ældre synspunkter. Ancel fremhæver en række stadier i udviklingen. Der gøres rede for en nu forladt anskuelse, hvorefter socialt forsvar betyder beskyttelse af samfundet mod kriminalitet, forsåvidt denne beskyttelse søges gennem kraftig repression overfor forbryderen. Nogle forfattere frygter at udtrykket ,social-forsvar" skal rumme fare for en tilbagevenden til tidligere tiders arbi- 
trære strafanvendelse. Efter en opregning af en række forfattere ,der kan tages til indtægt for en udvikling $\mathrm{i}$ denne retning, anf $\phi \mathrm{res}$ andre, der lægger vægten på et i ,socialt forsvar“ liggende synspunkt, hvorefter lovovertræderens „farlighed“ er det afg $\phi$ rende kriterium. Hvad det kommer an på er efter denne teori, at der anvendes sikkerhedsforholdsregler overfor den enkelte i forhold til hans evne til at gøre fortræd. Særlig gælder denne målestok overfor professionelle forbrydere og mentalt afsporede.

Fra denne opfattelse tager Ancel bestemt afstand. Socialt forsvar i „,ny betydning“ sigter ikke først og fremmest til samfundets krav om beskyttelse uanset hvad det må koste, men søger at kombinere forsvarsforanstaltninger med humanitet og rationalitet.

Efter en indgående historisk og komparativ fremstilling af det moderne sociale forsvars kriminalpolitik kommer forfatteren ind på det fremst $\varnothing \mathrm{d}$, der er gjort på dette område gennem Gramatica's grundlæggelse af foreningen Defence Sociale og de af denne forening organiserede kongresser. Det skjules ikke, at der har været nogen uoverensstemmelse mellem Gramatica og bl. a. Ancel med hensyn til foreningens praktiske målsætning. Medens Gramatica ville bryde radikalt med den traditionelle strafferet og kriminalpolitik og således helt ville afskaffe betegnelserne straf og forbrydelse, er Ancel talsmand for en langt mere modereret opfattelse. Han har ligeledes været primus motor $\mathrm{i}$ arbejdet med at skabe et program, der kunne akcepteres som et minimumsprogram af begge fløje indenfor foreningen. I den her omtalte bog giver Ancel et klart udtryk for, hvad der skiller hans syn fra ekstremisterne (s. 76):

„Der kan ikke blive tale om at afskaffe ideen om den enkeltes ansvarlighed... Tværtimod hviler det sociale forsvars kriminalpolitik faktisk på forestillingen om personlig ansvarlighed..." Ligeledes må pålæggelsen af den ene eller anden sanktion bero på en proces i strafferetsplejens form med dens garantier mod vilkårlighed og fejl i sagens behandling.

På senere steder i fremstillingen kommer forfatteren igen ind på, hvad der præger den nye bevægelse for socialt forsvar: den står afvisende overfor enhver metafysisk begrundelse af strafsystemet og adskiller sig derved fra den neo-klassiske straffilosofi. Set i forhold til positivismen fremhæver Ancel en række forhold, der adskiller denne bevægelse fra hans egen (s. $101 \mathrm{~mm}$.):

Det nye social-forsvar forkaster determinismen hos positivismen. Det nye social-forsvar kan ikke acceptere Gramatica's lære om forkastelse af det moralske ansvar. - Vi står her overfor det måske vigtigste skisma mellem de to bevægelser.

Forfatteren giver en kort, men brilliant oversigt over indflydelsen af defence sociale på retssystemerne verden over. Idet han trækker idehistorien op, beskæftiger han sig med 1) den religiøse retning, 2) den politiske, 3) den legale - vendt mod arbitrær strafanvendelse. 
Set i denne sammenhæng belyses påny defence sociale’s selvstændighed $\mathrm{i}$ forhold til andre bevægelser. Først og fremmest ytrer denne selvstændighed sig i dens forkastelse af metafysisk ideologi: „Dette punkt må understreges. Social defence lærer, at strafferetsplejen n $\varnothing d-$ vendigvis er relativ, og at dens funktion ikke er at dømme en isoleret handling $\mathrm{i}$ overensstemmelse med abstrakte regler, men at forårsage, at et menneske dømmes af andre mennesker. Menneskelig retfærdighed, administreret af mennesker er ude af stand til at opbygge et system, der er helt og holdent retributivt. Den dommer, der skal dømme, står ikke overfor det metafysiske problem om godt eller ondt... Opgaven er at afgøre, hvilke sanktioner der effektivt vil muligg $\phi$ re lovovertræderens genopdragelse ... og samfundets beskyttelse“.

I et afsluttende kapitel drager Ancel konklusionerne af sin undersøgelse. Han erkender, at den nye lære om socialt forsvar ikke så meget er en ny autonom doktrin som en sammenfatning af en gruppe eksisterende opfattelser. Udviklingen af socialforsvaret befinder sig i $\varnothing$ jeblikket ved en korsvej, men Ancel tvivler ikke om, at den rigtige vej er gjort farbar for den kommende tids udvikling.

Ancel's bog har krav på stor opmærksomhed. Den giver en klar og koncis fremstilling af et vanskeligt område af fundamental betydning for kriminalrettens udvikling i rationel og human retning. De anstrengelser, forfatteren $\mathrm{g} \phi \mathrm{r}$ sig for at placere det nye social-forsvar som udtryk for en ny „skole“ eller „,bevægelse“, hører dog ikke til bogens mest værdifulde afsnit og ligger formentlig noget udenfor skandinaviske kriminalisters interessefelt. Som helhed er bogen imidlertid af høj karat. Den er præget af Marc Ancel's på een gang blide og myndige tone, hans omfattende viden og glimrende fremstillingsevne.

Stephan Hurwitz.

International Criminal Law. Edited by Gerhard O. W. Mueller and Edward M. Wise. Fred B. Rothman, Hackensack, N. J. och Sweet \& Maxwell, London, 1965. $660 \mathrm{~s}$.

Det värdefulla verket ingår som del två i serien Publications of the Comparative Criminal Law Project vid New York University, vars ledare är den synnerligen produktive professor Mueller. I samma serie har också under 1965 professor Andenæs' Allminnelig strafferett utkommit i engelsk översättning som del tre under titlen The General Part of the Criminal Law of Norway.

Från New York University Comparative Law Project utgives också en serie av utländska strafflagar och straffprocesslagar $i$ engelsk översättning, som hittills räknar tio volymer.

Verket innehåller en mängd uppsatser och artiklar på den internationella rättens område, koncentrerade till folkrätt samt internationell straff- och straffprocessrätt. Flertalet av dem äro hämtade ur 
olika facktidskrifter, men en del ha skrivits för detta verk. Det är omöjligt att nämna alla verkets beståndsdelar, men bl. a. innehåller det samtliga konventioner på sistnämnda område och dessutom en del konventionsförslag, vissa av dem härrörande från ett forskningsprojekt vid Harvard omkring 1930 och ăterstoden huvudsakligen från FN.

Som inledning finns en av de grundläggande artiklarna på området "The Problem of an International Criminal Law", skriven 1950 av Georg Schwarzenberger.

Den följande framställningen är uppdelade i fem avsnitt, som gälla den territoriella behörigheten, internationella minimikrav på straffrättskipningen, sjöröveri och krigsförbrytelser, internationellt straffrättsligt och straffprocessrättsligt samarbete samt materiell internationell straffrätt.

I artikeln „The Proper Law of Crime in International Law" (s. 50769) av den indiske universitetsläraren Lotika Sarkar förekommer den enda hänvisningen till ett svenskt rättsfall ( $\mathrm{s}$. 56-57), nämligen NJA 1946 s. 65, där det gällde frågan, om en tysk soldat, som i det ockuperade Norge bedrivit mot Sverige riktat spioneri, kunde straffas härför vid svensk domstol. Han frikändes med tillämpning av folkrättsliga grundsatser, vilka ansågs skola tillämpas även inom den svenska straffrätten; Sarkar anser emellertid, att den svenska tolkningen var orealistisk och föredrager i stället två prejudikat från England och Sydafrika, både sammanhängande med det andra världskriget, som gått i motsatt riktning. Det förstnämnda av dessa gällde f. ö. den kände radiopropagandisten William Joyce, „Lord Haw-Haw“.

Muellers medutgivare Edward Wise, som från början var forskningsassistent åt honom, har skrivit en annan värdefull artikel „Note on International Standards of Criminal Law and Administration" (s. 135-163).

I det tredje avsnittet, som behandlar sjöröveri och krigsförbrytelser, finns bl. a. en kort artikel om det kända Santa Maria-fallet, „To Define and Punish Piracies - the Lesson of the Santa Maria" av Thomas M. Franck, som är professor vid New York University (s. 218-223). Han gör där gällande, att anledningen att kapten Henrique Galvaõs' och hans medsammansvurnas erövring av det portugisiska kryssningsfartyget Santa Maria i Karibiska sjön 1961 icke bedömdes som sjöröveri med en därav följande rättighet och skyldighet för samtliga nationers flottor i närheten att ingripa mot honom var att erövringen av fartyget skedde inifrån och av passagerare, medan det för sjöröveri fordras att angreppet sker från ett annat fartyg. För den svenska rättens del skulle brottet väl både efter reformen av förmögenhetsbrotten 1942 och enligt brottsbalken ha betraktats som grovt rån.

Avsnittet innehåller vidare bl. a. den enligt min personliga åsikt mest tankeväckande juridiska artikel jag läst på mycket länge, samtidigt ett av de två värdefullaste bidragen i boken. Det gäller artikeln „In re Eichmann: A Dilemma of Law and Morality" av Helen Silving 
(s. 290-353). Författarinnan är en av världens få kvinnliga straffrättsprofessorer och har sin professur vid University of Puerto Rico. I artikeln diskuterar hon dels Eichmannrättegången samt tvisten mellan Argentina och Israel inför FN i anledning av Eichmanns gripande i Argentina och transport till Israel och dels olika sätt att lösa detta problem. Vidare diskuterar hon ur mera filosofiska synpunkter rättsfallet och gör bl. a. gällande att Argentinas protest mot att främmande agenter inkräktat på dess territorium är en kvarleva av ett äldre juridiskt betraktelsesätt, där rättigheter betraktas som saker, medan hon tycker sig spåra och vill propagera för en modernare tendens att betrakta rättigheterna som ideer. Vidare gör hon gällande, att i sådana absoluta undantagsfall som beträffande Eichmann finns det en högre rätt, en kvarleva av naturrätten, vars valör tar över den nationella och positiva rätten.

Huvudredaktören Mueller har två längre bidrag, varav det ena "International Judicial Assistance in Criminal Matters" (s. 410-41) huvudsakligen behandlar möjligheterna till ett förbättrat straffrättsligt och straffprocessrättsligt samarbete mellan USA och Italien som en konsekvens av de amerikanska truppernas vistelse i Italien. I detta sammanhang kritiserar Mueller också med rätta kraftigt de rester av isolationistmentaliteten som fortfarande visa sig på sina håll i kongressen i form av en utpräglad misstro mot rättssäkerhetsgarantierna i alla andra system än det amerikanska.

Muellers andra artikel, som bör betecknas som det mest värdefulla bidraget jämte Helen Silvings nyssnämnda artikel behandlar „The United Nations Draft Code of Offences against the Peace and Security of Mankind: An American Evaluation“ (s. 597-628). Häri diskuterar Mueller bl. a. de amerikanska invändningarna mot en internationell strafflag ur fyra olika synpunkter, nämligen de känslobetonade, de juridiska, de praktiskt-politiska och de juridiskt-teoretiska. Särskilt sistnämnda grupp (s. 616—23) innehåller en rad vägande invändningar mot den alltför teoretiska uppläggningen av förslaget och dess bortseende från vanliga juridiska principer. Mueller ansluter sig icke för egen del till ett förslag av Jerome Hall att man bör starta med ett betydligt anspråkslösare förslag till en internationell strafflag, innefattande t. ex. sjöröveri (även i luften), skadegörelse på undervattenskablar på internationellt vatten, internationell förfalskning, vit slavhandel och narkotikahandel. Däremot anser han att förslaget behöver omarbetas betydligt för att nå en tillfredsställande standard och att vidare avsaknaden av effektiva sanktionsmedel gör dess praktiska värde mycket tvivelaktigt.

Som ett sammanfattande omdöme kan verket varmt rekommenderas. 
Tony Parker \& Robert Allerton: The Courage of his Convictions. Hutchinson \& Co. London 1962.

Blandt den righoldige og stadig $\varnothing$ gende str $\varnothing \mathrm{m}$ af forbryder-biografier indtager denne bog en smuk plads. Den skildrer en professionel tyv og røvers opvækst og udfoldelse til storforbryder med en række straffe, der har berøvet ham friheden i en trediedel af hans liv, og som nu truer med at skulle afløses af en mangeårig internering. Bogens værdi ligger navnlig i dens hensynsløse ærlighed og usminkede livsfilosofi. Han er opvokset under de dårligst tænkelige sociale vilkår og har under disse udviklet en barsk kynisme, hvis hovedlinie er, at han ikke for nogen pris vil tilpasse sig et borgerligt liv i anstændig fattigdom. Han fortryder intet af, hvad han har gjort, og han tager de mange straffedomme der er overgået ham, som en uafvendelig erhvervsrisiko.

Størstedelen af bogen er formet som et interview mellem ham og skriftets udgivere, hvem det er lykkedes at trænge ind $\mathrm{i}$ hans psyke og vinde hans tillid uden sentimentalitet fra nogen af siderne.

Litterært ligger denne bog på et højt plan. Den er knap og klar i sine formuleringer. $\mathrm{Og}$ den er af betydelig interesse for alle, der beskæftiger sig med behandlingen af professionel kriminalitet. Ikke for intet har bogen vakt Arthur Koestler's opmærksomhed. Han siger bl. a.: „Denne intime selvbiografi er en afsløring - den rummer den første psykologiske indsigt i mentaliteten hos det afskrækkende, gådefulde og patetiske produkt af vort samfund: den professionelle forbryder".

Stephan Hurwitz.

\section{NYUDKOMMEN LITTERATUR}

Dalgard, Odd Steffen: Abnorme Lovovertredere. Universitetsforlaget, Oslo 1966. $166 \mathrm{~s}$.

Bestemmelser om Fengselsvesenet 1965. Utgitt av Fengselsstyret. Oslo 1966. $125 \mathrm{~s}$.

Straffelovsrådets Betænkning om Strafferetlig Forældelse m. v. Betænkning nr. 433. Kbhvn. 1966. $50 \mathrm{~s}$.

Actes du XIVe Cour's International de Criminologie: L'Equipement en Criminologie. Masson \& Cie, Editeurs. Paris 1965. 583 s.

Beretning om Fængselsvasenet i Danmark 1963. Afgivet af Direktøren for Fængselsvæsenet. Nyborg 1966. $101 \mathrm{~s}$.

Annales Internationales de Criminologie. Bulletin de la Société Internationale de Criminologie. Paris 1965. $551 \mathrm{~s}$.

Gibbins, T. C. N.\& R. H. Ahrensfeldt: Cultural Factors in Delinquency. Tavistock Publications. London 1966. $201 \mathrm{~s}$. 